\title{
PEMBUATAN BIOBATERAI BERBASIS AMPAS KELAPA DAN TOMAT BUSUK
}

\author{
MUHAMAD ABIDIN $^{1,2^{*}}$, ASHARY FATHUL HAFIDH ${ }^{1}$, MiA WIDYANINGSIH $^{1}$, MUHAMMAD YUSUF $^{2}$, DAN \\ ANCEU MURNIATI ${ }^{1}$
} ${ }^{1}$ Jurusan Kimia, Fakultas Sains dan Informatika, Universitas Jenderal Achmad Yani,
Jalan Terusan Jenderal Sudirman, Cimahi

${ }^{2}$ Pusat Riset Bioteknologi Molekuler dan Bioinformatika, Universitas Padjadjaran, Jalan Singaperbangsa Nomor 2, Bandung

*alamat email korespondensi: muhamadabidin321@gmail.com

\begin{tabular}{l}
\hline Informasi Artikel \\
\hline Riwayat Naskah : \\
Diterima pada 26 \\
November 2019 \\
Diterima setelah \\
direvisi pada 24 Juni \\
2020
\end{tabular}

Diterbitkan pada 30

Juni 2020

Kata Kunci: Baterai; ramah lingkungan; tomat; ampas kelapa.

Keywords: Battery; Enviromental Friendly; Tomato; Coconut's Pulp.

\begin{abstract}
Abstrak/Abstract
Indonesia merupakan negara tropis dengan produksi kelapa dan tomat yang cukup tinggi. Pada tahun 2016, Indonesia menjadi negara penghasil kelapa terbesar di dunia dengan produksi kelapa sebanyak 18,3 juta ton. Beberapa produksi pengolahan kelapa menghasilkan produk samping berupa ampas kelapa. Disisi lain, dari 916.000 ton produksi tomat pertahun terdapat $80 \%$ yang mengalami kebusukan akibat serangan hama. Kedua limbah tersebut berpotensi untuk diolah menjadi baterai ramah lingkungan. Tomat busuk telah diketahui dapat dijadikan sebagai elektrolit ramah lingkungan pada baterai dengan menghasilkan beda potensial pada baterai sebesar 1,233 Volt. Oleh karena itu, tujuan penelitian ini yaitu membuat baterai ramah lingkungan berbahan dasar ampas kelapa dan tomat busuk. Ampas kelapa ditambahkan karena emulsifying tepung kelapa secara signifikan lebih tinggi dibandingkan tepung kaya serat lainnya. Metode yang digunakan adalah mencampurkan tomat busuk dengan ampas kelapa dengan variasi komposisi 0, 25, 50, 75 dan 100\% pada masing-masing konsentrasi. Parameter yang diamati dalam penelitian ini adalah potensial, kapasitas, dan daya baterai. Hasilnya, baterai pada komposisi 0, 25, 50, 75 dan 100\% menghasilkan rata-rata beda potensial masing-masing sebesar 1,$27 ; 1,17 ; 1,45 ; 1,23 ;$ dan 0,02 Volt, arus listrik masing-masing sebesar 0,$76 ; 1,13 ; 0,97 ; 0,24$; dan $0 \mathrm{~mA}$, dan daya masingmasing sebesar 0,$97 ; 1,56 ; 1,43 ; 0,30 ; 0,00$ miliwatt. Kondisi optimum baterai diperoleh pada baterai dengan konsentrasi $25 \%$ ampas kelapa berbanding tomat busuk dengan daya sebesar 1,56 miliwatt. Penelitian ini diharapkan dapat berkontribusi pada pengembangan baterai ramah lingkungan untuk mengurangi limbah B3, seiring dengan meningkatnya kebutuhan akan baterai di era revolusi industri 4.0.
\end{abstract}

\begin{abstract}
Indonesia is a tropical country with a fairly high production of coconut and tomato. In 2016, Indonesia became the largest coconut producing country in the world with coconut production of 18.3 million tons. .There are side products in some producing coconut products, such as pulp. On the other hand, there were $80 \%$ of rotten tomatoes due to pest attack, out of 916,000 tons of tomato production per year. Both of these wastes have the potential to be processed into environmentally-friendly batteries. Rotten tomatoes have been known to be used as environmentally friendly electrolytes in batteries by generating a different potential in a battery of 1.233 Volts. Therefore, this work aims to develop an environmentally friendly battery based on coconut pulp and rotten tomatoes. Coconut pulp was added because emulsifying coconut flour is significantly higher than other flour. The rotten tomatoes were mixed with coconut pulp with variations in the composition of 0,25 , 50, 75, and $100 \%$ at each concentration. The parameters observed in this study were the potential, electrical current, and battery power. As a result, batteries in the composition of 0, 25, 50, 75 and 100\% generated an average potential difference of 1.27 each; 1.17; 1.45; 1.23; and 0.02 Volts, electric current of 0.76; 1.13; 0.97; 0.24; and $0 \mathrm{~mA}$, and power of 0.97; $1.56 ; 1.43 ; 0.30 ; 0.00$ milliwatts, respectively. The optimum condition of the battery was obtained from the battery with a concentration of $25 \%$ coconut pulp ratio rotten tomatoes with a power of 1.56 milliwatts. This result is expected to contribute to the development of environmentally friendly batteries to reduce dangerous waste, along with the increasing need for batteries in the fourth industrial revolution.
\end{abstract}

\section{PENDAHULUAN}

Negara Indonesia merupakan negara tropis dengan keanekaragaman flora dan faunanya.
Indonesia merupakan negara penghasil kelapa dan tomat yang cukup tinggi. Pada tahun 2016, produksi kelapa di Indonesia sebanyak 18,3 juta ton [1]. Sayangnya, beberaaa produk olahan kelapa 
menghasilkan produk samping berupa ampas kelapa. Disisi lain, Indonesia menghasilkan 916.000 ton produksi tomat pertahun [2] namun, terdapat $80 \%$ yang mengalami kebusukan akibat serangan hama [3]. Kedua limbah tersebut berpotensi untuk diolah menjadi baterai ramah lingkungan. Baterai yang saat ini digunakan menghasilkan limbah Bahan Beracun Berbahaya (B3), karena dalam baterai sel kering, seng digunakan sebagai anoda, karbon sebagai katoda, dan campuran mangan dioksida, seng klorida, dan amonium klorida sebagai elektrolit [4]. Selain itu, terdapat pula logam berat seperti; $\mathrm{Pb}, \mathrm{Cd}, \mathrm{Ni}, \mathrm{Co}$, Cr [5] dan Li [6]. Sehingga sulit terurai oleh mikroba dan sangat berbahaya, jika limbah baterai tidak ditanggulangi dengan benar dan tepat maka akan terjadi pencemaran pada lingkungan [7]

Logam Kadmium (Cd) dapat menyebabkan keracunan kronis dan menjadi faktor yang menyebabkan emfisema, osteomalasia, anemia, serta kelumpuhan pada tubuh manusia. Kadmium dari baterai juga dapat mengontaminasi tanah dan air, yang akhirnya masuk ke tubuh manusia, menyebabkan kerusakan hati dan ginjal, serta dapat menyebabkan tulang lunak atau kecacatan tulang berat [8]. Baku mutu kadmium di perairan yang ditetapkan dalam Peraturan Pemerintah Republik Indonesia Nomor 82 tahun 2001, sebesar 0,01 $\mathrm{mg} / \mathrm{L}[9]$.

Logam lainnya yang terkandung dalam baterai adalah logam timbal $(\mathrm{Pb})$. Logam timbal $(\mathrm{Pb})$ merupakan racun saraf (neurotoxin) yang bersifat kumulatif, destruktif dan kontinu pada sistem haemofilik, kardio-vaskuler dan ginjal. Anak yang telah menderita tokisisitas timbal cenderung menunjukkan gejala hiperaktif, mudah bosan, mudah terpengaruh, sulit ber-konsentrasi terhadap lingkungannya. Biasanya orang akan mengalami keracunan timbal bila ia mengonsumsi timbal sekitar 0,2 sampai $2 \mathrm{mg} /$ hari [10].

Litium merupakan salah satu unsur yang juga terkandung dalam baterai, efek pemaparan jangka pendeknya yaitu gangguan pada mata, kulit, dan saluran pernapasan. Jika terhirup, zat ini dapat menyebabkan edema paru-paru [11].

Banyaknya dampak negatif dari kandungan baterai yang saat ini digunakan, maka dari itu diperlukan solusi baterai ramah lingkungan, yaitu biobaterai. Bio-baterai adalah perangkat penyimpanan energi yang didukung oleh senyawa organik [12] yang berdasarkan pada prinsip, proses dan aplikasi di dalam kehidupan sehari-hari sehingga perlu pembelajaran yang mencakup konten, konteks, dan proses sains [13]. Bio-Baterai dapat menghasilkan listrik yang menyediakan sumber daya portabel berkelanjutan dan sesuai permintaan [12].
Berdasarkan paten S00201904048, tomat busuk telah diketahui dapat dijadikan sebagai elektrolit ramah lingkungan pada baterai dengan menghasilkan beda potensial pada baterai sebesar 1,233 Volt [14]. Oleh karena itu, tujuan penelitian ini yaitu membuat baterai ramah lingkungan berbahan dasar ampas kelapa dan tomat busuk.

Ampas kelapa ditambahkan karena emulsifying tepung kelapa secara signifikan lebih tinggi dibandingkan tepung kaya serat lainnya [15]. Penambahan ampas kelapa terhadap tomat busuk menjadikan elektrolit berbentuk padat.

\section{EKSPERIMEN}

Eksperimen yang dilakukan mengacu pada prosedur pembuatan BAMAT (Baterai Tomat) [12]. Metode dikembangkan dengan menambahkan ampas kelapa terhadap tomat busuk.

\section{Material}

Material yang digunakan pada penelitian ini yaitu baterai bekas, tomat busuk dan ampas kelapa

\section{Instrumentasi}

Beberapa instrumen yang digunakan pada penelitian ini adalah Digital Multimeter VIPER DT830B dan Multiparameter METTLER TOLEDO Seven Excellent.

\section{Prosedur}

Prosedur pembuatan biobaterai ampas kelapa dan tomat busuk mengacu pada paten S00201904048.

\section{Pembuatan Jus Tomat Busuk}

Tomat busuk dihaluskan dengan menggunakan blender selama 10 menit tanpa tambahan cairan sampai halus sehingga diperoleh jus tomat busuk. Selanjutnya, jus tomat busuk disaring dan diambil filtratnya,kemudian disimpan didalam wadah.

\section{Pengujian Tingkat Keasaman Jus Tomat Busuk}

Jus tomat busuk yang telah disaring, diuji tingkat keasamannya dengan menggunakan $\mathrm{pH}$ meter.

\section{Pembuatan Tepung Ampas Kelapa}

Ampas kelapa dikeringkan selama 3 hari di bawah sinar matahari hingga kering dan tidak menggumpal. Selanjutnya, ampas kelapa 
dihaluskan menggunakan penggiling sampai menjadi tepung, diayak menggunakan ayakan 50 mesh. Tepung ampas kelapa hasil pengayakan selanjutnya disimpan.

Pembuatan Elektrolit Campuran Tepung Ampas Kelapa dan Jus Tomat Busuk

Tepung ampas kelapa dicampurkan dengan jus tomat busuk menggunakan perbandingan $\mathrm{b} / \mathrm{v}$ ( $\mathrm{g} / \mathrm{mL})$ dengan komposisi $0,25,50,75$ dan $100 \%$ pada wadah yang berbeda.

\section{Perakitan Biobaterai}

Baterai AA dilepaskan pelapis tabungnya menggunakan cutter dan obeng minus,kemudian dibuka bagian atas baterai,. ditarik katoda baterai secara perlahan. Selanjutnya, isi baterai dikeluarkan sampai tabung seng (anoda) baterai kosong (tidak mengandung elektrolit).

Baterai yang sudah kosong diisi dengan variasi konsentrasi elektrolit, selanjutnya dimasukkan katoda yang diperoleh dari Baterai AA, kemudian ditutup dengan penutup baterai hingga rapat.

\section{Pengujian Biobaterai}

Pengujian biobaterai dilakukan dengan menggunakan multimeter. Baterai dihubungkan dengan multimeter. Kutub positif pada baterai dihubungkan dengan kutub positif pada multimeter yang ditandai dengan kabel berwarna merah. Kutub negatif pada baterai dihubungkan dengan kutub negatif pada multimeter yang berwarna hitam.

\section{HASIL DAN PEMBAHASAN}

\section{Jus Tomat Busuk}

Tomat yang digunakan yaitu tomat busuk dengan karakteristik tekstur yang sudah tidak padat dan mengeluarkan cairan, seperti terlihat pada Gambar 1 dan Jus yang diperoleh dapat dilihat pada Gambar 2.

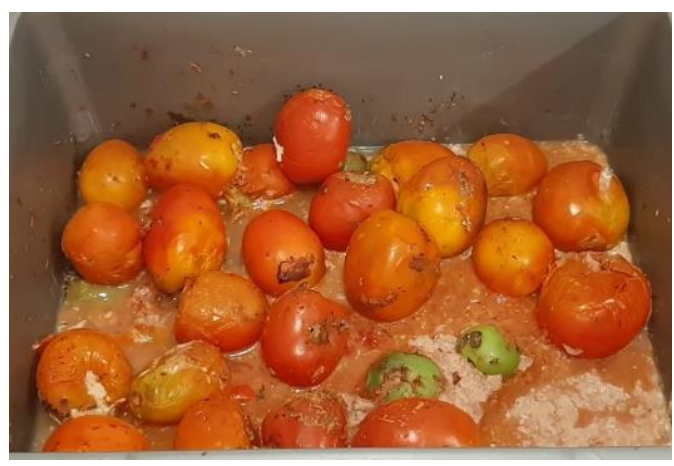

Gambar 1. Tomat busuk.

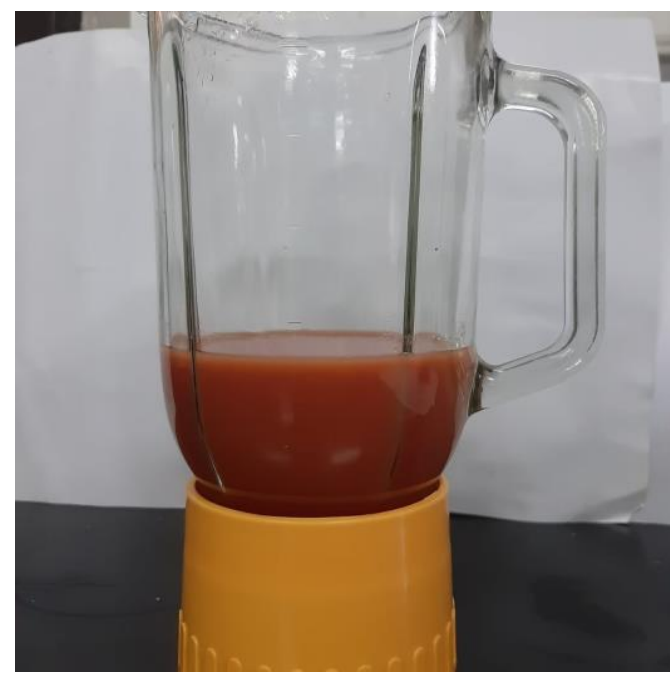

Gambar 2. Jus tomat busuk.

\section{Tingkat Keasaman Jus Tomat Busuk}

Buah tomat memiliki rasa masam sehingga cocok dijadikan elektrolit. Pengujian tingkat keasaman tomat menggunakan $\mathrm{pH}$ meter dilakukan untuk mengetahui tingkat keasaman tomat secara akurat. Pada penelitian ini buah tomat yang digunakan memiliki pH 4,9. Gambar 3 menunjukkan proses pengujian tingkat keasaman jus tomat busuk.

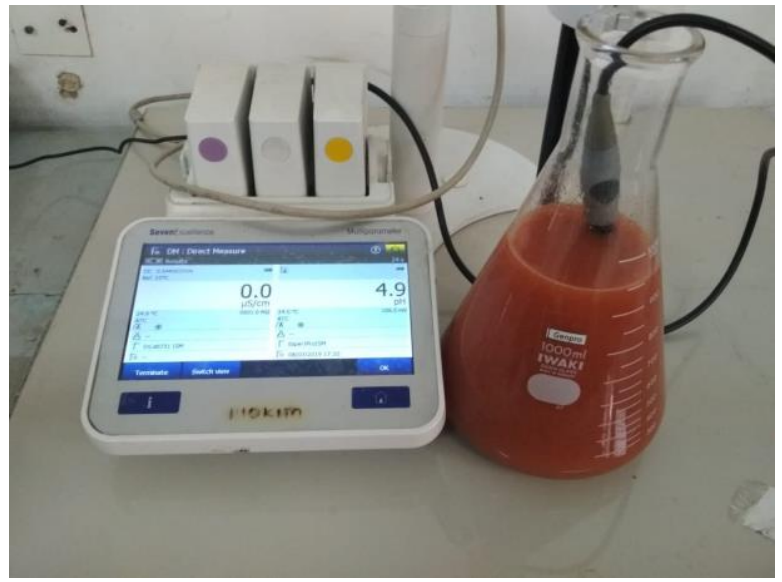

Gambar 3. Pengujian tingkat keasaman tomat busuk.

\section{Tepung Ampas Kelapa}

Ampas kelapa yang digunakan merupakan limbah dari produk santan. Setelah diperoleh, ampas kelapa dikeringkan, kemudian digiling hingga membentuk tepung, seperti terlihat pada Gambar 4. 


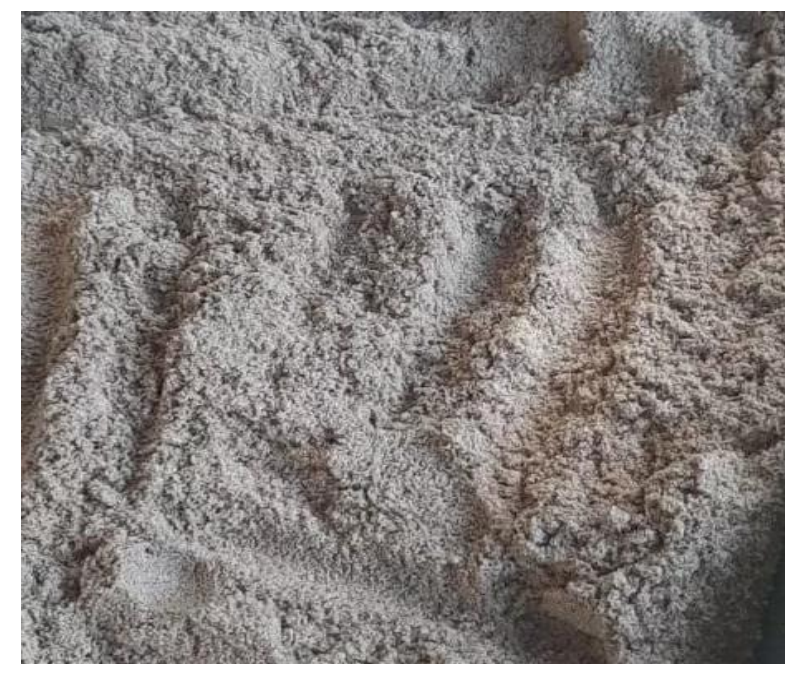

Gambar 4. Tepung ampas kelapa.

\section{Elektrolit Campuran Tepung Ampas Kelapa dan Jus Tomat Busuk}

Ampas kelapa yang telah menjadi tepung, dicampurkan dengan jus tomat busuk. Gambar 5 menunjukkan campuran elektrolit ampas kelapa dan tomat busuk.

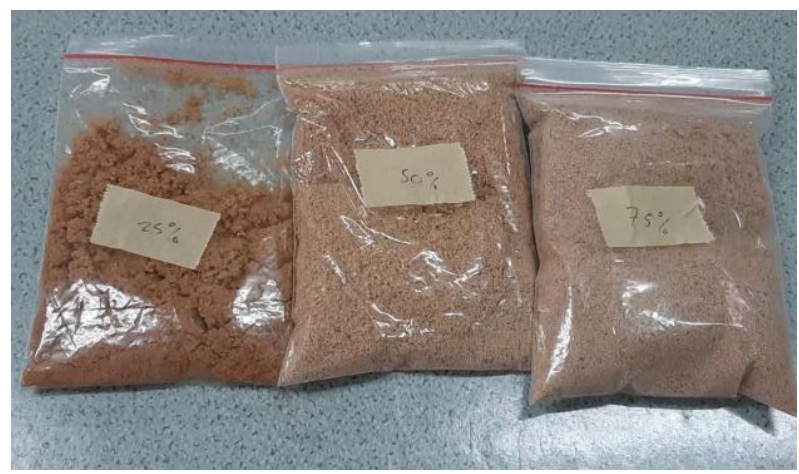

Gambar 5. Campuran elektrolit ampas kelapa dan tomat busuk.

\section{Hasil Pengujian Biobaterai}

Biobaterai yang telah siap, diukur dengan menggunakan multimeter. Terdapat 6 replikasi pada tiap-tiap konsentrasi elektrolit. Hasil pengujian beda potensial (V) dan kuat arus (mA) terhadap biobaterai disajikan pada Tabel 1.

Nilai beda potensial yang dihasilkan mendekati nilai beda potensial baterai komersil yaitu 1,5 Volt, sedangkan nilai arus yang dihasilkan oleh biobaterai ampas kelapa dan tomat busuk masih belum optimal.

Berdasarkan hukum Ohm, fenomena ini diduga terjadi karena besarnya nilai hambatan sistem baterai.

$V=I \times R$

$$
\text { dengan, } \begin{aligned}
\text { V } & =\text { Beda Potensial }(\text { Volt }) \\
\mathrm{I} & =\text { Kuat Arus }(\mathrm{A}) \\
\mathrm{R} & =\operatorname{Hambatan}(\mathrm{Ohm})
\end{aligned}
$$

Semakin kecil hambatan, maka semakin besar kuat

\begin{tabular}{|c|c|c|c|c|}
\hline \multicolumn{2}{|c|}{ Konsentrasi/\% } & \multirow[b]{2}{*}{ Baterai } & \multirow{2}{*}{$\begin{array}{c}\text { Beda } \\
\text { Potensial } \\
\text { (Volt) }\end{array}$} & \multirow{2}{*}{$\begin{array}{l}\text { Arus } \\
(\mathrm{mA})\end{array}$} \\
\hline $\begin{array}{l}\text { Ampas } \\
\text { Kelapa }\end{array}$ & Tomat & & & \\
\hline \multirow{7}{*}{0} & \multirow{7}{*}{100} & $\mathrm{I}$ & 1,36 & 1,16 \\
\hline & & II & 1,33 & 0,69 \\
\hline & & III & 1,31 & 0,85 \\
\hline & & IV & 1,42 & 0,76 \\
\hline & & $\mathrm{V}$ & 1,30 & 0,82 \\
\hline & & VI & 0,95 & 0,31 \\
\hline & & Rata-rata & 1,27 & 0,76 \\
\hline \multirow{7}{*}{25} & \multirow{7}{*}{75} & I & 1,28 & 1,86 \\
\hline & & II & 1,20 & 1,05 \\
\hline & & III & 1,32 & 2,00 \\
\hline & & IV & 1,34 & 2,19 \\
\hline & & V & 1,29 & 0,83 \\
\hline & & VI & 0,59 & 0,05 \\
\hline & & Rata-rata & 1,17 & 1,33 \\
\hline \multirow{7}{*}{50} & \multirow{7}{*}{50} & I & 1,53 & 1,61 \\
\hline & & II & 1,47 & 0,52 \\
\hline & & III & 1,31 & 0,49 \\
\hline & & IV & 1,42 & 1,34 \\
\hline & & V & 1,46 & 1,39 \\
\hline & & VI & 1,56 & 0,54 \\
\hline & & Rata-rata & 1,46 & 0,98 \\
\hline \multirow{7}{*}{75} & \multirow{7}{*}{25} & I & 1,03 & 0,14 \\
\hline & & II & 1,33 & 0,16 \\
\hline & & III & 1,05 & 0,14 \\
\hline & & IV & 1,54 & 0,42 \\
\hline & & V & 1,48 & 0,45 \\
\hline & & VI & 1,00 & 0,16 \\
\hline & & Rata-rata & 1,23 & 0,25 \\
\hline \multirow{7}{*}{100} & \multirow{7}{*}{0} & I & 0,03 & 0 \\
\hline & & II & 0,65 & 0 \\
\hline & & III & 0,01 & 0 \\
\hline & & IV & 0,01 & 0 \\
\hline & & V & 0,03 & 0 \\
\hline & & VI & 0,02 & 0 \\
\hline & & Rata-rata & 0,12 & 0 \\
\hline
\end{tabular}
arus yang dihasilkan.

Tabel 1. Hasil pengujian biobaterai

Analisis dilanjutkan dengan melihat grafik perubahan konsentrasi terhadap beda potensial dan kuat arus yang dihasilkan untuk mengetahui kondisi campuran elektrolit terbaik antara ampas kelapa dan tomat busuk

Gambar 6. adalah grafik konsetrasi ampas kelapa:tomat busuk (\%) terhadap beda potensial (V). 


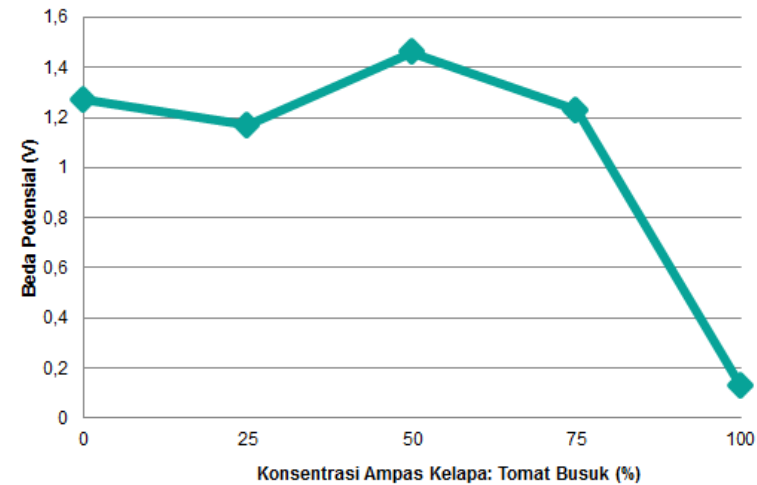

Gambar 6. Grafik konsetrasi ampas kelapa:tomat busuk (\%) terhadap beda potensial (V).

Dalam pengujian beda potensial biobaterai, konsentrasi terbaik yaitu pada konsentrasi ampas kelapa berbanding tomat busuk 50\%.

Gambar 7. adalah grafik konsetrasi ampas kelapa:tomat busuk (\%) terhadap kuataArus (mA)

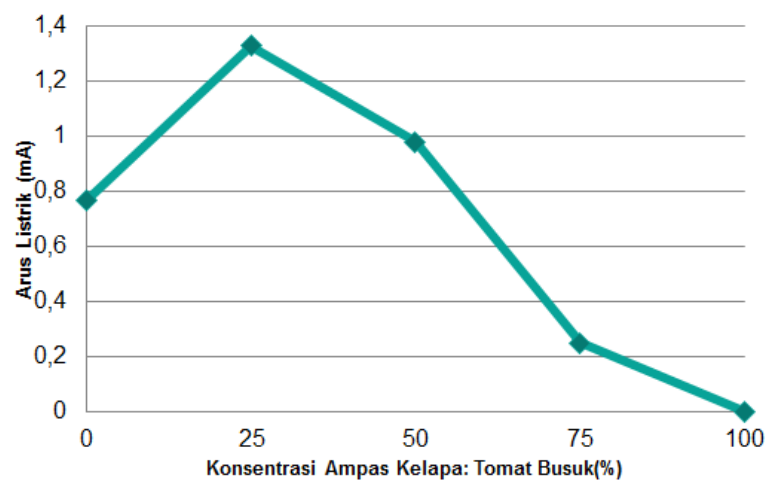

Gambar 7. Grafik konsetrasi ampas kelapa: tomat (\%) terhadap kuat arus (mA).

Dalam pengujian kuat arus biobaterai, konsentrasi terbaik yaitu pada konsentrasi ampas kelapa berbanding tomat busuk $25 \%$.

Kondisi baterai yang paling optimum belum diketahui dikarenakan belum adanya satu jenis konsentrasi elektrolit baterai yang memiliki beda potensial dan arus tertinggi. Selanjutnya, analisis dilakukan dengan meninjau hubungan antara beda potensial dan arus listrik, dalam arti lain, analisis dilakukan dengan menghitung rata-rata daya yang dihasilkan.

$$
\begin{aligned}
P=V \times I & \\
\text { dengan, } & \mathrm{P}=\text { Daya }(\text { Watt }) \\
\mathrm{V} & =\text { Beda Potensial }(\mathrm{V}) \\
\mathrm{I} & =\text { Kuat Arus }(\mathrm{A})
\end{aligned}
$$

Gambar 8. adalah grafik konsetrasi ampas kelapa:tomat (\%) terhadap daya (Watt)

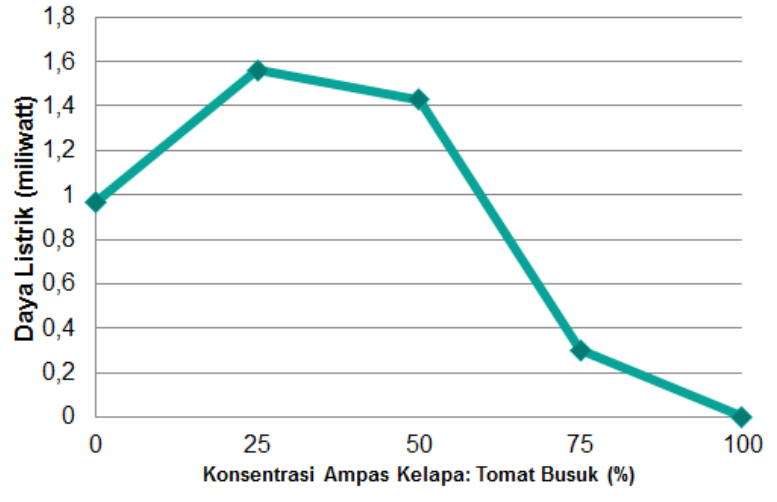

Gambar 8. Grafik konsetrasi ampas kelapa: tomat busuk $(\%)$ terhadap daya (miliwatt).

Berdasarkan grafik hubungan antara beda potensial, arus, dan daya, diketahui bahwa baterai dengan konsentrasi $25 \%$ ampas kelapa berbanding tomat busuk merupakan baterai dengan kondisi optimum. Hal ini diketahui karena daya yang dihasilkan oleh baterai dengan konsentrasi $25 \%$ ampas kelapa berbanding tomat busuk, paling tinggi yaitu sebesar 1,56 miliwatt. Kondisi terbaik selanjutnya yaitu baterai dengan konsentrasi $50 \%$ ampas kelapa berbanding tomat busuk yang memiliki daya 1,43 miliwatt, baterai dengan konsentrasi $100 \%$ tomat busuk yang memiliki daya 0,97 miliwatt, baterai $75 \%$ ampas kelapa berbanding tomat busuk yang memiliki daya 0,30 miliwatt, dan yang terakhir baterai dengan konsentrasi $100 \%$ ampas kelapa yang tidak memiliki daya dikarenakan nilai arus yang diperoleh tidak ada atau nol.

Telah dilakukan pengujian dan dipatenkan [14] bahwa tomat busuk dapat menerima listrik ketika dilakukan recharging. Pengujian dilakukan pada baterai D (BAMAT) dengan konsentrasi $100 \%$ jus tomat busuk menghasilkan tegangan mula-mula sebesar $0,90 \mathrm{~V}$ dan tegangan setelah recharging sebesar $1,23 \mathrm{~V}$.

Kelebihan penelitian ini dibandingkan dengan penelitian sebelumnya [14] adalah melakukan duplikasi sebanyak 5 kali dan melakukan analisis untuk mengetahui nilai kuat arus dan daya dari biobaterai yang dibuat. Selain itu, dengan komposisi yang sama dengan biobaterai BAMAT [14] diketahui bahwa baterai dengan elektrolit $25 \%$ ampas kelapa dan $75 \%$ tomat busuk lebih baik dibandingkan dengan baterai yang mengandung elektrolit $100 \%$ jus tomat busuk (BAMAT) dengan perbandingan daya 1,56 miliwatt berbanding 0 . BAMAT hanya memiliki beda potensial, namun belum menghasilkan nilai kuat arus saat dilakukan pengukuran kuat arus.

Sebelumnya telah dilaporkan pula, bahwa tomat busuk dapat dijadikan sebagai sumber energi listrik. Daya yang dihasilkan pada $10 \mathrm{mg}$ tomat 
busuk menghasilkan 0,3 watt [16]. Jika dikalkulasikan, 80\% [3] tomat busuk dari 916.000 ton produksi tomat [2], akan menghasilkan 732.000 ton tomat busuk. Tomat busuk 732.000 ton setara dengan 732.000.000.000.000 mg tomat busuk. Berdasarkan laporan [16] maka, setiap tahunnya Indonesia akan memiliki daya listrik dari tomat busuk sekitar 2,196 X $10^{14}$ watt.

Potensi listrik yang dihasilkan dari biobaterai ini dapat terus dikembangkan untuk menunjang perangkat elektronik yang membutuhkan daya listrik yang rendah ataupun perangkat elektronik dengan daya listrik tinggi setelah dilakukan optimasi baik dari kajian kimia ataupun kajian elektro, sehingga dihasilkan baterai sesuai dengan kebutuhan.

\section{SIMPULAN}

Berdasarkan penelitian yang telah dilakukan, diketahui bahwa baterai dengan konsentrasi $25 \%$ ampas kelapa berbanding tomat busuk merupakan baterai dengan kondisi optimum dengan daya yang dihasilkan sebesar 1,56 miliwatt.

\section{UCAPAN TERIMA KASIH}

Diucapkan terimakasih kepada semua pihak yang telah membantu penelitian dan penyusunan makalah ini, khususnya kepada Universitas Jenderal Achmad Yani dan Pusat Riset Bioteknologi Molekuler dan Bioinformatika Universitas Padjadjaran

\section{REFERENSI}

[1] J. Burton, "The World Leaders In Coconut Production", World Atlas, 19 April 2018. [Online]. Available: https://www.worldatlas.com/articles/theworld-leaders-in-coconut-production.html.

[2] Y.Y. Riezqi, "Indonesia Surplus Tomat 900 Ribu Ton/Tahun", sindonews, 17 Agustus $2015 . \quad$ [Online]. Available: https://ekbis.sindonews.com/read/1033874/3 4/indonesia-surplus-tomat-900-ributontahun-1439790704.

[3] T.S. Uhan and R.E. Suriaatmadja, "Pengendalian ulat buah tomat (Helicoverpa armigera Hubn.) dengan insektisida organophosphat dan pirethroid buatan", Buletin Penelitian Hortikultura, vol. 25, no. 4, pp. 29-34, 1993.

[4] M.I. Hidayat and Suprapto, "Pemisahan Mangan Dioksida $\left(\mathrm{MnO}_{2}\right)$ dari Limbah Pasta Baterai dengan Metode Elektrolisis", Jurnal
Sains dan Seni ITS, vol. 6, no. 2, pp. 23373520, 2017.

[5] Iswanto, Sudarmaji, E.T. Wahyuni, and A.H. Sutomo, "Timbulan Sampah B3 Rumah Tangga dan Potensi Dampak Kesehatan Lingkungan di Kabupaten Sleman, Yogyakarta", Jurnal Manusia dan Lingkungan., vol. 23, no. 2, pp. 179-188, 2016.

[6] S. Hidayat, C. Leonardo, M. Kartawidjaja, W. Alamsyah, and I. Rahayu, "Sintesis Polianilin Dan Karakteristik Kinerjanya Sebagai Anoda Pada Sistem Baterai Asam Sulfat", Jurnal Material dan Energi Indonesia , vol. 6, no. 1, pp. 20-21, 2016.

[7] A. Nurmala, C.Z. Subarkah, and C.D.D. Sundari, "Penerapan Model Task Based Learning Untuk Mengembangkan Literasi Kimia Mahasiswa Pada Pembuatan BioBaterai", Prosiding SNIPS, pp. 821-825, 2016.

[8] V.F. Bararah, "Banyak yang Tidak Tahu Bahaya Buang Baterai Bekas.," detik health, 17 Maret 2011. [Online]. Available: http://health.detik.com/read/2011/03/17/133 809/1594158/763/banyak-yang-tidak-tahubahaya-buang-baterai-bekas?199110175.

[9] R.A. Marwah, Supriharyono, and Haeruddin "Analisis Konsentrasi Kadmium (Cd) dan Timbal $(\mathrm{Pb})$ Pada Air dan Ikan dari Perairan Sungai Wakak Kendal", Aquares, vol. 4, no. 3, pp. 37-41, 2015.

[10] D. Gusnita, "Pencemaran Logam Berat Timbal $(\mathrm{Pb})$ di Udara dan Upaya Penghapusan Bensin Bertimbal”, Berita Dirgantara, vol. 13, no. 3, pp. 95-101, 2012.

[11] lenntech, "Chemical properties of lithium," lenntech, 2019. [Online]. Available: https://www.lenntech.com/periodic/elements /li.htm.

[12] U.Z. Siddiqui and A.K. Pathrikar, "The Future of Energy Bio Battery", International Journal of Research in Engineering and Technology, vol. 2, no. 11, pp. 2319-1163, 2013.

[13] N. Jayashantha, K.D. Jayasuriya, and R.P. Wijesundera, "Biodegradable Plantain Pith for Galvanic Cells". Proceedings of the Technical Sessions, vol. 28, pp. 92-99, 2012.

[14] M. Abidin, A. Murniati, F.I. Apriliany, and A.M. Kristiyani, "Metode Pembuatan "BAMAT" Inovasi Energi Terbarukan Berbasis Baterai bekas dan Tomat Busuk", 
Indonesia Paten S00201904048, 16 Agustus 2019.

[15] T.P. Trinidad, Coconut Flour From "Sapal"; A Promising Functional Food, Manila: Food and Nutrition Research Institute, Department of Science and Technology, 2002.
[16] Ryan, "You could soon power your home with TOMATOES: Scientists develop battery cells that use waste fruit to generate electricity", Science \& Tech. Mail Online, 2016 Maret 2016. [Online]. Available: https://www.dailymail.co.uk/sciencetech/arti cle-3494879/You-soon-power-homeTOMATO-Scientists-develop-battery-cellsuse-waste-fruit-generate-electricity.html. 